Portland State University

PDXScholar

2014

\title{
Américo Castro, Saint James, and Spain: the History of a Belief
}

Daniel Blanchard

Portland State University

Follow this and additional works at: https://pdxscholar.library.pdx.edu/honorstheses

\section{Let us know how access to this document benefits you.}

\section{Recommended Citation}

Blanchard, Daniel, "Américo Castro, Saint James, and Spain: the History of a Belief" (2014). University Honors Theses. Paper 80.

https://doi.org/10.15760/honors.57

This Thesis is brought to you for free and open access. It has been accepted for inclusion in University Honors Theses by an authorized administrator of PDXScholar. Please contact us if we can make this document more accessible: pdxscholar@pdx.edu. 
Américo Castro, Saint James, and Spain: The History of a Belief

Daniel Blanchard

Honors Thesis

Advisor: Dr. John S. Ott

11 June 2014 
The present essay is broadly interested in the problem of writing history, and the way different manners of confronting this problem are received and represented in the modern day as our historiographical compass increases in depth, scope, and capacity. Because of the breadth of this theme, it is necessary to limit myself to the case of a single author, admittedly a morsel of this project's potential magnitude. The case of Américo Castro, however, a Spanish historian of the twentieth century (1885-1972), represents this essay's broader concerns in historiography. Castro's work, particularly his magnum opus España en su historia (pub. 1948), embodies not only the intellectual trends of the Spanish thinkers of his day, but also a substantial swath of Western philosophy and academic production, epitomizing the varied ways in which historians were coming to grips with post-war, nationalistic interests.

Given my focus on Castro's making of a national epic, perhaps a Spanish author serves as an extreme example. It will be demonstrated that Spain's identity crisis was far more profound than its European neighbors', on account of what Julián Marías described as its amnesic tendency. Spain intrinsically understands itself; "Pero a veces se olvida," says Marías, "cuando los espejos exteriores le devuelven imágenes deformadas y acaso contradictorias de sí mismo."1 Nevertheless, the extremity of Spain's existential, national inquiry marks its direct relevance to the volatile state of political and social affairs in twentieth-century Europe. As a direct consequence, present-day scholars have perceived Castro and his contemporaries as part of an empirically corrupt heritage. Castro's efforts to address the problem of writing history, or to come to grips with national identity at all for that matter, have lost their validity as historically reliable narratives. Lost in the present day's inheritance of these works of history, however, is their value as testimonies of their time's intellectual currents. They have become the primary 
texts of a past era's intellectual history. They deserve fuller theoretical treatment, and the beauty of historiography is that it allows us the time to consider them as the primary texts that they are.

Castro was among the first Spanish historians who argued the roots of Spanishness were to be found in the Middle Ages. His idea was that the essence of Spain lay in its culture, a culture that took shape through a dialectical process of interfaith relations, from the Muslim conquest of Iberia in 711, until their expulsion along with the Jews in 1492. Spain subsequently fashioned itself on a caste-bound myth, a nationality limited to its Christian past, hinging it on superficial values that demonstrated the growing self-doubt of the Spanish people. In just one example, Castro convincingly finds the roots of this essentialism in the fifteenth-century writings of Fernando de la Torre, an aristocratic converso from Castile. De la Torre's words reveal "a passionate desire for justification and a defensive purpose," says Castro. ${ }^{2}$ Ultimately bewildered, he seems to ask, "What is Spain and what is her worth?"3 Castro claws at his insecurity, arguing, "Into the conscious awareness of his own history De la Torre incorporates his own grief over feeling incapable of providing certain cultural necessities; to be much, to do little."4

De la Torre's doubts over Spain's worth epitomize the inchoate, late medieval stages of its existential crisis. His efforts to cover up its imperfections are the beginning of what Castro terms Spain's process of vivir desviviendose, or living in denial of the self. For Castro, when the Catholic Monarchs expelled the Muslims and Jews from Iberia in 1492, they were acting on the indomitable beginnings of the process of Spain's living in denial of itself. It was the early modern writers that picked up this myth of the Spanish in their history and propelled it into the nineteenth and twentieth centuries. 
Castro demonstrates, however, that the problem of Spain's existential crisis has a beginning far earlier than the time of Fernando de la Torre, and even Ferdinand and Isabella. Rather, the Middle Ages in their entirety, in Castro's perspective, contributed to the buildup of Spain's identity crisis. The Early Middle Ages, which for Spain is marked by the conversion of the Visigoths to Christianity in the late sixth century, proved to be the transition of Iberia from a Roman, Germanic, and pagan past to an embryonic age of the making of Spanishness. Evident in Castro's idea of the inception of Spain is the advent of the Christian faith during the Visigothic period. But, of course, the Visigoths' shift to Christianity is only the beginning of the story. Spain does not truly begin to pronounce itself until the emergence of one of the most salient icons of medieval Christendom in Iberia: Saint James, or in his peculiarly Spanish appellation, 'Santiago Matamoros,' Saint James Slayer of Moors.

I. Saint James, his cult and military order

In order to evaluate Castro's historiographical reception it will be necessary to consider an aspect of his vision of Spanish history that is manageable within the context of a brief essay. His idea of Saint James proves a logical basis for discussion because of its representative quality of his broader philosophy of history. Castro introduced his idea of the saint in his 1948 text España en su historia. He revised the text two times, producing new editions in 1954, renamed La realidad histórica de España and translated as The Structure of Spanish History by Edmund L. King under Castro's close supervision, and he revised it again in 1962. These reworked editions integrated new chapters and further defenses of Castro's historical philosophy into the narrative of the original text. While Castro made these additions, his conception of Saint James remained the same. José Rubia Barcia noted, "For Don Américo, Santiago is not of Galicia, but of Spain, and although he deletes, adds and revises some chapters in the successive editions of 
España en su historia, he always includes, with slight modifications, the chapters on Santiago as the central and main key for the understanding of Spanish history." ${ }^{5}$ Furthermore Castro published a defense of his idea of the saint in his 1958 text Santiago de España, in which he made clear that the saint was "integrated into the vital entity of Spain." ${ }^{6}$ In the following brief overview, I will sketch the history of Saint James, his cult, and the military order named for him in the Middle Ages through a non-Castro trajectory. This perspective will prove valuable when juxtaposed with Castro's. I will argue, however, that the history of Saint James and his cult is just as much a "history of a belief" as Castro reveals Spain to be.

The seventh-century Breviarium Apostolorum is the earliest, non-disputed record documenting the details of Saint James' life and preaching in Iberia. The early-medieval writers of the text believed James had preached in Spain, but then returned to the Holy Land where he was executed by Herod Agrippa, commonly held in the biblical tradition as the cruel oppressor of Christ's apostles. "King Herod laid violent hands upon some who belonged to the church," reads Acts 12:1. "He had James, the brother of John, killed with the sword." After his death, the creed of the cult of Santiago has it that James' remains were saved from the dogs outside of Jerusalem and brought to Jaffa, where his rescuers sailed for seven days with his body before reaching the western coast of Spain, at the mouth of the Ría de Arosa to be exact. ${ }^{7}$ After a series of miracles and continuing their trip up the river to Padrón, James' disciples managed to bury the body on Mount Ilicino in present-day Galicia. There, through centuries of neglect, the saint's tomb became derelict, only to be rediscovered by Bishop Teodomiro of Iria in $814{ }^{8}$

Constructing this myth of James' life and preaching is the difficult balance of Biblical, medieval, and early-modern sources. They range from the contested early-seventh century writings of St. Isidore of Seville, which survive in a thirteenth century manuscript, to the eighth- 
century writings of Julian of Toledo. Even the Franciscan humanist Diego Murillo played a role in constructing James' myth during the Counter-Reformation. In his Fundación milagrosa de la Capilla de la Madre de Dios de Pilar (pub. 1616) he insisted on James' role in founding the basilica at Nuestra Señora del Pilar. The span of sources composing James' myth presents the problem of the extent to which medieval thinkers believed that Saint James had preached in Spain. This has been a matter of much debate. T.D. Kendrick argued that the doubts of the saint's myth, which naturally surfaced amid the institutionalization of his cult, have not debunked the evidence of the belief of medieval peoples in James' miracles. Similarly, church historian R.A. Fletcher found evidence for their belief in the annals of the Historia Compostellana, a twelfthcentury book of deeds commissioned by Diego Gelmírez, Archbishop of Santiago de Compostela (1120-49). ${ }^{9}$ While Fletcher does acknowledge that later writers embellished the story, Katherine Elliot Van Liere held that the tradition of James preaching in Iberia was purely an early-modern construction, when Erasmian humanism, which allowed for less skepticism of the cult of saints, enjoyed a revival in Spain during the Counter-Reformation. ${ }^{10}$ While more attention may not be given to this debate here, ample evidence of medieval peoples' belief in Saint James rests in the rise of his cult.

The cult of Saint James built upon the tradition that he had preached in Spain, and that he was buried on Mount Ilicina. With the initial successes of the Reconquista securing safe passage for Christian travelers in northern Spain, the pilgrimage to Santiago de Compostela began to see a rise in popularity by the ninth century. Of course, the fame of James' tomb in Galicia had already been disseminated through Christendom. Even before the discovery of his tomb a hymn had been written in his honor. The hymn cites James as the "caput refulgens aureum Ispanie," "potitus Ispania," "tutor," and "patronus nobis," already signs of his growing cult. ${ }^{11}$ After the 
time of the tomb's discovery a charter of disputed authorship known as the 'Voto de Santiago,' which only survives in a twelfth-century manuscript, dates the first mandatory tributes to Santiago de Compostela to 829, during the reign of Alfonso II of Asturias (forerunner of the Kingdom of León). ${ }^{12}$ The pilgrimage itself, however, contributed greatly to the prosperity of James' cult and the Cathedral of Santiago de Compostela. The famous 'Pilgrim's Guide,' attributed to twelfth-century monk Aymeric Picaud, describes an already well defined, deeply tracked road to the tomb by his time. Importantly, Picaud credits the ease of access of the way to Saint James to the efforts of Pope Callistus II, Alfonso VI of Castile, and the archbishop of Santiago de Compostela Diego Gelmírez, a particularly significant figure in the institutionalization of James' cult. "May the souls of these men and those who worked with them rest in eternal peace!" declares Picaud. ${ }^{13}$

Further development of the cult occurred with the foundation of the military order of Santiago sometime in the later twelfth century. Derek Lomax dates its origins to 1170, the year Fernando II of León sacked Cáceres. Subsequently a Spanish knight named Pedro Fernández founded a brotherhood known as "Los freiles de Cáceres," from its inception a militaristic order bent on defending the newly conquered territory of the king in Extremadura. ${ }^{14}$ A year later the order renamed itself under the title of Saint James, "probablemente," says Lomax, "a causa de un acuerdo hecho con don Pedro, arzobispo de Santiago, quien entró en la Orden como freile honorario." ${ }^{15}$ In exchange Pedro Fernández, the first master of the order, was received as a canon in the cathedral of Santiago de Compostela. ${ }^{16}$ The order performed its military function, privately commissioned by the various Spanish kingdoms from the time of its inception through the Reconquista, and even continued honorifically as Spain expanded into the New World. 


\section{Castro and Saint James}

Rather than considering Castro's idea of Saint James in a context external to his own philosophy of history, as the previous brief overview has done, the following section clarifies how the saint functions within it. To Castro the saint is not a happening, isolated in the context of its historical place. He is integrated into the very living experience of Spanishness. From this exercise it can be gleaned that Castro's idea of Saint James is qualified within his own philosophy of history, that the Saint functions according to, and is a product of, the historical process of Spain's self-fashioning.

Saint James in Castro's view is an historical phenomenon that may make little sense to the reader without first considering the theoretical framework within which the idea operates. Castro informs his reader early in The Structure of Spanish History that his unique method of viewing history cannot be grasped solely by logic or reason. ${ }^{17}$ The first and most fundamental framework to grasp is the idea that Spain is constituted of a vital essence, made up by the collective belief of a people, and reflected in its cultural productions. "Spain was a faith, a belief," says Castro, "fed by life and by death, by heaven and by earth. ${ }^{18}$ Castro gives context to such an abstraction by integrating the philosophy of Miguel de Unamuno (1864-1936) into his historical narrative. In his 1912 text Del sentimiento trágico de la vida, Unamuno who wrote of the Spanish people's vital connection between the empirical and spiritual conditions of life. Unamuno describes Spain as a "land under heaven" and "full of heaven." ${ }^{19}$ It is constituted of body and soul. Castro finds "ten centuries of yearning existence" throbbing in Unamuno's lyricism. ${ }^{20}$ Unamuno expresses an existential crisis that is intrinsic to Spain, its "primordial phenomenon." 21 Spain has faced an initial and constant problem since the Middle Ages, a problem of "insecurity and anguish concerning its own existence, its uncertainty, its living in a 
state of alarm caused by doubt." 22 Effectively Castro's philosophy of history is to take up this existential crisis in the context of historical inquiry. In doing so he aims not only to preserve, but also accurately to represent the vital essence of Spanishness.

Castro uses the basis of existential philosophy to coin his own terms, composing an historical structure that accommodates his unique way of viewing history. These terms materialize from the basic notion that, for Castro, "historical life consists in an inner trajectory or process in which external motivations acquire form and reality; that is, they are converted into deeds and events that have a meaning." ${ }^{23}$ In other words, an historical agent's environmental circumstances determine the agent's existence, which is reflected in the agent's actions and productions, "never identical with that of any other human community." ${ }^{24}$ As deeds reflect the existential condition of the agent, the "inwardness" or "peculiar physiognomy of a people," they also define the historical form and reality of a people. ${ }^{25}$ Thus deeds carry meaning on several levels for Castro. On the one hand they determine the mode of life, what Castro terms the "dwelling place of life" (morada vital), which is the way an agent is perceived in its history as having existed on account of its actions. ${ }^{26}$ On the other hand, deeds represent "living structure," or vividura. ${ }^{27}$ Living structure reflects the "mode according to which" the agent operates. Morada vital and vividura are the dialectical essences that, for Castro, activate historical inquiry, enabling a critical process that reveals to the historian the actual existential condition of a people. Naturally Castro viewed this method as distancing the historian from the kind of deterministic biases that informed his predecessors, because the actual historical agent can be understood according to its own environmental circumstances, rather than the value-laden judgments of the historian himself. 
The relationship between morada vital and vividura is not a dialectic entirely unique to Castro's philosophy of history. The two terms actually bear many similarities to other formulas of philosophical inquiry. Caroll B. Johnson has noted their resemblance to Marx and Engels' "infrastructure and superstructure," Saussure's "langue and parole," Chomsky's "surface and deep structure," and Freud's "behavior and motivation (conscious and unconscious)." ${ }^{28}$ What Castro has done, however, is coined a dialectic that accommodates for Spain's unique historical problem. The two essences activate a structuralist perspective of reality that allows for social and religious interplay to materialize in a theoretical framework.

Castro applies the dialectic of morada vital and vividura to the existential condition of the Iberian peoples in the Middle Ages. By examining the dialectic across the Peninsula's dominant religious groups, namely Christians, Muslims, and Jews, Castro determines that their cultural traditions merged with one another significantly. This cultural interplay, what Castro terms "living togetherness," or convivencia, effectively amounted to a pluralistic Iberian society. For Castro the process of convivencia is an unrelenting, omnipresent dialectic between cultures. The process entails an interplay that is not limited to peacetime exchange. On the contrary, in many cases the interplay becomes most pronounced through deeds of violence, as is especially apparent in the emergence of the Hispanicized Christians of northwestern Iberia in the eighth and ninth centuries.

It is in the eighth and ninth centuries that Castro demonstrates that the Christians living along the strip of territory along the Atlantic in northern Iberia, especially the most isolated Galicians in the Northwest, began to take on their peculiarly Spanish vividura. Cut off from their Visigothic roots, the Christians of northern Spain began to adapt to their new environmental circumstances, which entailed an abundance of interaction with the Muslims that had conquered 
Visigothic Spain in the early eighth century. From these interactions Christians gleaned a "host of things—-material and human—created by the Moors." ${ }^{29}$ This process of convivencia eventually yielded medieval Christian Spain, "the result of the combination of an attitude of submission and wonder in the face of a culturally superior enemy and of the effort to overcome this very position of inferiority." ${ }^{30}$ As the passage suggests, Castro argued that the Spanish had acculturated both peaceful and militant practices from the Muslims, on account of which their vividura began to reflect their disposition in the form of cultural production.

Castro qualifies his philosophy of history via this theoretical framework of "livingtogetherness," what is in itself determined by "the dwelling place of life" and "living structure." It makes perfect sense, then, that when Castro introduces Saint James into the mix, the Saint embodies the traits that he does, and subsequently represents such a watershed in the trajectory of Spanish history. Indeed, Castro refers to the saint as Spain's "axis," an entity that propels the dialectical process of Spain's self-fashioning through the later Middle Ages and into modernity. ${ }^{31}$ At the crux of Castro's idea of Saint James is the Saint's embodiment of "theobiosis." 32 Constituting Spanish belief in the Saint is an amalgamation of folkloric, pagan spiritual tradition, Christian creed, and Muslim influence. The Galician people's instigation of this theobiosis is a product of what had transpired in their "dwelling place," isolated by circumstance from the rest of Christendom, and solidified by their active opposition to the objective and extra-personal religious forms that made up Christianity in the broader European context of the ninth century. ${ }^{33}$ On one end of this theobiosis is a lingering pagan spirituality that campesinos had preserved in the relatively isolated frontier society of Visigothic Iberia, what was a vestige of the Peninsula's Roman days. On another end is the recent, and overwhelming colonial presence of the Muslims that rapidly brought on the devastation of the Visigothic political administration in the early 
eighth century, and became thoroughly saturated in the Iberian "dwelling place" by the ninth. On yet another end of the theobiosis is the uniquely Galician form of Christianity, a personalized and indomitable belief that resulted from the precarious situation of a constant confrontation with Muslim expansion. ${ }^{34}$ Effectively it is a direct consequence of Galicia's structural circumstances, their "dwelling place," that Saint James, the expression of Galicia's "living structure," takes on the peculiar traits that he does.

Before further detail of Castro's Saint James is presented, it must be emphasized that these broader concepts composing Castro's representation of the Saint are directly related to his theoretical framework of history. Castro reminds his readers of the quality of his synthesis not as a manipulation of mere historical events, but as a consideration of the "vital points of view, the feelings of a people as they faced the world around them." ${ }^{35}$ The unique qualities of the Spanish people came into their own through Christian Iberia's existential crisis, precipitated by the conditions of life in a frontier society, ridden with violence, and composed of various ethnoreligious groups interacting on both peaceful and militant terms. This existential condition, as Castro sees it, takes form via the dialectic between morada vital and vividura, both the essences that eventually determine Spain's peculiar habits and manners of existing. ${ }^{36}$ And again, unique to Spain is the circumstance of convivencia, the umbrella term that encompasses all of these processes, and in the ninth century materializes in the theobiotic figure of Saint James.

Castro describes the pagan element of Saint James as constituting an important place in the rise to eminence of James' cult. While the belief that James was the son of Zebedee, a fisherman from Bethsaida, became orthodox by the thirteenth century, as the Castilian poet Gonzalo de Berceo's Poema de Fernán González illustrates, it was held in popular Galician tradition in the early Middle Ages that James was actually a brother of Jesus. ${ }^{37}$ This belief came 
from, one, the legacy of the Dioscuri which had survived in Spanish folklore, and two, a misreading of the Gospel of Matthew, which addressed James as the brethren of the "carpenter's son" (Matt. 13:55). With respect to the latter conflation, Castro explains the verse was no doubt not meant to be taken literally, but it was because of the lingering essence of the former that theologians in Christian Iberia were so willing to extrapolate the message of the scripture to its status quo in Galicia in the early Middle Ages. ${ }^{38}$ The Dioscuri were in Roman and Greek belief the twin sons of Jupiter, Castor and Pollux, militant equestrian gods frequently depicted in classical art as riding white horses into battle. Numerous parallels may be drawn between the two cults, such as the belief that one brother, Castor in the pagan tradition, "ascended to heaven while the other remained on earth (at least for some time) as a protector of man." ${ }^{39}$ To juxtapose James' relationship with Jesus in the popular belief of the early cult of Saint James shows clearly a similarity between the two traditions.

In Castro's view, the adamant belief among Spanish Christians that Saint James was a brother of Jesus was only able to reach such profundity because of the second element composing the Saint's theobiosis: the Muslim invasion. "If Spain had not been submerged by Islam," Castro says, "the cult of Santiago of Galicia would not have prospered." ${ }^{40}$ It is to say, if the Christians had not been conquered by the Muslims, they would not have learned how to conquer the Muslims in return. This dominance required the centralization of the belief of the Hispano-Christian people in an entity like Saint James, who is, to Castro, a "counterMohammed."11 As Mohammed had inspired the Islamic conquest of the Peninsula, Saint James served a similar role as inspiration for "reconquest." ${ }^{42}$ Such a notion echoes the previous discussion of Castro's understanding of "dwelling place" and "living structure." The Saint, embodying classical tropes that had existed in the belief of the people for hundreds of years, 
syncretized with the Muslim tradition of a strong concentration of belief on a militant and prophetic figure in the form of a uniquely Spanish Christianity: precociously militant and composed of various syncretic elements. This theobiosis, in Castro's view, made up the new "living structure" of Spanishness, and it would constitute Christian mores on the Peninsula throughout the Middle Ages.

Crucial to Castro's idea of Saint James is its implications within his philosophy of history, because his treatment of the Saint entails more than simply identifying its syncretic elements. For Castro, the belief in Saint James is vitally connected to the Spanish essence. Again, he describes the nature of this essence on the basis of existential philosophy. "Out of the belief in Santiago grows a most original type of existence," explains Castro. ${ }^{43}$ The belief, a kind of ex machina perspective of the Saint, comes to determine the way of life, the "living structure," of the Spanish people. ${ }^{44}$ This structure is the militant framework that constituted Spanish society in the Middle Ages. At the same time the belief in Saint James defines the "dwelling place" of Spanish existence. Deeds are expressed in cultural manifestations, which take the form of "works of anguished beauty (from Cervantes to Unamuno), in which life appears as it is, as a problem."45 The same existential crisis Unamuno speaks of in the twentieth century, this "uncertainty" and "living in a state of alarm caused by doubt," permeates the Spanish people's anxiety about their origins, their place within their multi-cultural structure of life. ${ }^{46}$ Saint James thus is an expression of an irrational and instinctive process. This framework is the philosophy of history in which Castro views the cult of Saint James.

However much credence one can viably put in the empirical evidence Castro uses to back his argument, it is important to remember that his idea of history is not necessarily based on a system of "logical reason." ${ }^{47}$ He writes, "History, that is to say, the integral life of a peoples, is 
not a sequence of 'events,' isolable by means of logical abstractions." 48 "History does not take place in a vacuum but in the life of a people." ${ }^{49}$ For understanding Spanish history, it is not whether the reader objectively agrees with the evidence of the faith in Saint James, the critical process of a rational inquirer. Rather, the understanding is hinged on grasping the existential reality of the Spanish people, one undeniably immersed in a kind of irrational and illogical belief. Castro describes this belief as a matter of life or death for the Spanish. "Peoples incapable of dying for a faith have never attained a complete reality," he says. ${ }^{50}$ This is the kind of belief the Muslims of Iberia clung to, and the kind the Christians learned to own as well. "We are such stuff as dreams are made of," quotes Castro, reminding his readers that the dream of a people, when "integrated into the total existence of millions," is a reality, and "reality is a dream." ${ }^{51}$

III. The historiographical legacy

Historians have filtered Castro's philosophy of history, and effectively his interpretation of the history of the cult of Saint James, through the legacy of the debate surrounding Spanish national character. The tendency of this historiography is to Castro's detriment, as the richness of his philosophical construct is lost. The recent work of Martín F. Ríos Saloma, for example, epitomizes this tendency. Ríos Saloma's sole treatment of Castro in his survey of twentiethcentury Spanish historiography of the Reconquista is limited to how Castro, along with his most outspoken critic Claudio Sánchez-Albornoz, debated over the Spanish national character and polemicized against Franco-era Spain. Ríos Saloma describes neither Castro nor SanchezAlbornoz's unique philosophies of history beyond the fact that they rooted their arguments in the Spanish Middle Ages, and focused particularly on the Castilian-Leonese origins of Spanishness. ${ }^{52}$ Ríos Saloma viewed both authors' writings as interpretive, ethereal, and ambiguous. ${ }^{53}$ While he is right to highlight the famous debate over the origins of the Spanish 
essence between Castro and Sanchez-Albornoz, and moreover to emphasize the focus of their debate on the Castilian origins of the Spanish character, it is Ríos Saloma's utterly abridged and incomprehensive treatment of both authors that exemplifies the typical superficiality with which they are received today.

Both Castro and Sánchez-Albornoz used distinct historical philosophies that determined their definition of the Spanish essence. These philosophies were not ethereal or ambiguous, as Ríos Saloma suggested, but rather their understanding is naturally dependent on a full consideration of the factors that determine their methods of viewing historical space. As it can be judged from the discussion of Castro's idea of Saint James, these methods are constructs that both authors expend considerable time and effort explaining.

Sánchez-Albornoz's idea of the Spanish essence taking root in the conversion of the Visigoths to Christianity in the seventh century, only for the essence to become adulterated with the Umayyad invasion of Iberia in 711, has understandably lost its popularity in the past few decades as histories have incorporated perspectives of religious tolerance and cultural pluralism. ${ }^{54}$ Concomitantly, Castro's definition of the Spanish essence germinating in nearly four centuries of cohabitation on the Peninsula between Christians, Muslims, and Jews, from approximately the time of the Umayyad invasion until the catalysts for the Reconquista crescendoed in the eleventh and twelfth centuries, has been held in higher esteem for its nonEurocentric approach to the Spanish Middle Ages.

It should be noted that both Castro and Sanchez-Albornoz found the source of the Spanish essence in Castile-León, which by the thirteenth century included Galicia, because of the Frankish influence evident in the Catalonian and Portuguese regions, and the eventual unification of Catalonia with Castile-León in the fourteenth century. While their determination is disputable, 
it must be remembered that both authors sought to extinguish the influence of Krausism and the perspective of broader, European influences on the Spanish kingdoms throughout the Middle Ages. Rather Castro looked for what he determined to be the most authentically isolated institutions, in his view the most Hispanic, to find the root of Spanish national identity. Inevitably this limitation led him to the Castilian and Leonese regions of central and northwestern Iberia due to their relative seclusion from European interplay during the Early Middle Ages.

Present scholarship of the Reconquista, removed from the biases of the Franco era, has moved on to elaborate on the dynamic nature of medieval Europe. By looking explicitly at the influence of the papacy, this historiography has described Spain's Reconquista as more of a consequence of crusader ideology stemming from the late-eleventh century than a uniquely Spanish institution. Joseph F. O'Callaghan represents a constituent of this new, what he calls "pluralistic," perspective, a reference to the multi-faceted nature of the Crusades. While the papacy called on Christendom's adherents to make the pilgrimage eastward, to many it was more attractive to travel and fight in Iberia, a theater of the Crusades to a great extent ignored by previous scholars. O'Callaghan explained, however, that it was largely French knights that led the earliest religious wars of "reconquest" in the Catalonian region prior to the First Crusade. While the knights' efforts were mostly unsuccessful, they represented the growing interest of the papacy in the Reconquista. O'Callaghan demonstrates this interest by highlighting Count Ebles de Roucy's participation in the Reconquista under papal approbation, which took the form of an expedition to Catalonia in $1068 .{ }^{55}$ Ultimately, by the time of Pope Gregory VII (1073-85), the Reconquista had taken a role in the European consciousness and was thus a broader European phenomenon, not solely a Spanish one. 
Inevitably O'Callaghan's study aims to debunk Castro's dialectical concept of the Reconquista by emphasizing the role of the Church in propagating the idea of the crusader's martyrdom in Iberia. In this sense the role of devotion to the cult of Saint James could not have simply been a reflection of Muslim jihadist ideals, but was rather a Christian ideal for which O'Callaghan finds evidence in the earliest, Augustinian writings on holy war. ${ }^{56}$

In the end, the understanding of the Reconquista's origins, whether via O'Callaghan's "pluralism" or Castro's convivencia, is determined more by the historian's selection of sources than the validity of one theory over the other. Castro looked for the more isolated evidence, while O'Callaghan looked more broadly in the sources for potential European influences. Castro's analysis of the Reconquista is valid within his method of viewing history, just as O'Callaghan's is valid within his own, pluralistic perspective of the Crusades. Specific to Castro is his effort to expand on the progression of the Reconquista through the lens of his vitalist philosophy of history. Within this framework, to view the Reconquista as a broader European institution is to deny the role of the Spanish vividura in the making of its living structure. Castro's philosophy of history therefore qualifies his analysis of the origins of Reconquista in that it works to produce an existential and cultural understanding of the Spanish people for which O'Callaghan's perspective does not allow.

José Luis L. Aranguren criticized Castro's idea of the Reconquista in much the same vein as O'Callaghan, denouncing Castro's method on account of its "lay bias." Aranguren claimed Castro had been far too immersed in the "extra-establishment" ideology of his peers in the Centro de los Estudios Históricos during his formative years, which entailed the overt application of the existentialist perspective of history previously described. Aranguren found Castro's dialectic unsuited for matters that he deemed only fit to be dealt with through the lens of 
religiosity. ${ }^{57}$ While undeniably Castro does invest close attention to religion in his perspective of the Reconquista, as his idea of Saint James demonstrates, his understanding of religiosity is ultimately informed by an existentialist construct that, for Aranguren, distorts the institutional reality of the war against Islam in Iberia. Despite Aranguren's criticism, he admits that "Castro's work deserves to be considered a work of art, comparable in the field of history to Burckhardt, and comparable, for the skeptic Paul Valéry, to the most rigorously, the most architecturally conceived philosophical constructions." 58

To receive Castro's thought either positively or negatively is, in the end, determined by one's method of viewing history. While Aranguren acknowledges the "art" in Castro's vision of medieval Spain, he is more adamant in emphasizing the role of ecclesiastical institutions, rather than Castro's dialectic, in spurring the Reconquista into full motion in the later Middle Ages. This is typical of Castro's critics. Historians have jettisoned their willingness to view history as a vital space, in which the human experience is expressed through cultural manifestations and is a result of the structural circumstances of life. On account of this shift in thought the quality of Castro's vitalist perspective of medieval Spain has found little resonance in the historiography of the last half-century. Rather historians such as O'Callaghan and Aranguren are more apt to conceptualize the human experience in terms of institutional developments, a socio-economic focus that Castro resisted adamantly. "As soon as the units of life, be they collective or individual," writes Castro, "are conceptualized, they turn into corpses ... when we reduce corpses to types we are proceeding to form a museum of desiccated plants or animals." ${ }^{59}$ Castro's perspective, idealist or not, maintains the human quality of medieval Spain. It views the "units of life" within their living context, and allows for cultural manifestations primarily to speak for 
themselves. This understanding is exclusive of the method O'Callaghan and Aranguren use to explain the progression of the Reconquista.

It is not, however, the case that all scholars of the past half-century have filtered Castro's work solely through the Reconquista, the debate on Spanish national identity, or that they see him as a polemical writer at all, for that matter. In an article published in 1972, Oriol Pi-Sunyer presented Castro's dialectic as an accurate framework with which to perceive the past, and an earnest effort to invigorate historical inquiry with a vitality that is all too often missing in the field. "The business of both the anthropologist and the historian," writes Pi-Sunyer, "is not so much the description of the exotic or the temporally distant, as the ordering of cultural and social information into some internally consistent pattern or structure. ${ }^{60}$ To critique society on such a plane entails the elaboration of a "processural model" that offers a degree of "time depth" to the society under question. ${ }^{61}$ It is a diachronic approach that inevitably entails the consideration of both past and present phenomena in the enterprise of reaching a coherent understanding of a society in its history. To be sure, to work through a longue durée of the kind Pi-Sunyer explains is both an objective and subjective exercise. This is, however, the invigorating quality of such depictions of the past, especially when written by "indigenous" historians who have essential connections to the subject society. ${ }^{62}$

What the reader is left with, then, is the paradox that Castro was both objective and subjective in his writing, that while he avoided deterministic interpretations of the Spanish past, he also was an "indigenous" historian of Spain and inevitably fettered to the conflict of the Franco Era. Evident in Castro's analysis of Saint James is a definite effort to demonstrate an internal structure within the Spanish experience in the Middle Ages, a structure that seeks to define the existence of a people on both conscious and unconscious planes, much like the 
anthropologist does. Saint James also represents part of a greater whole, a piece of the "processural model" that illuminates Spain's totality. For Pi-Sunyer, this method is what distinguishes Castro's version of Spanish history. Readers, Pi-Sunyer argues, need to examine Castro's formulations as analysts of human societies rather than as historians. He demands to be received, either positively or negatively, on the basis of his own philosophy of history. To consider Castro merely a polemicist is to deny the value of his work with respect to the internal character of the Spanish living experience.

Castro himself addressed critics who considered his work polemical. While he embraced the zeitgeist of twentieth-century Spain, saying the present is a complexity integrated with the past, he also denounced subjectivity in historical inquiry. ${ }^{63}$ For one, he resisted the classification of his method as deterministic by emphasizing the reality of his concept of historical space within the existence of a people. ${ }^{64}$ On the other hand, Castro is conscious of the historical fallacies committed by his all too subjective, nineteenth-century predecessors in the field. He elicits their patriotic versions of Spanish history of the nineteenth century, which presented all matters Iberian under the glorious pendant of Reconquista. Castro argued his predecessors' conclusions were clear reflections of the evidence available to them, but that they ignored the value of the sources as testimonies of the historical agent's actual existential condition. ${ }^{65}$ Castro makes it clear that the historian must be purely objective. This perspective, for Castro, can only be realized by submerging oneself in history, getting rid of patriotism, as well as bitterness. ${ }^{66}$ It also requires the historian to take risks, which Castro sees his investigation as doing by presenting the history of Spain through such a novel framework as existentialist philosophy. Castro invokes this framework explicitly when he says, "Especially in studying a historic life that consists in insecurity must the historian rid himself of all insecurity. He must accept the totality 
of the data in all their fullness, the noble with the paltry, thinking of how the two interlock." 67 The very insecurity that instigates the rise of Saint James' cult as an expression of Christian Spain's inferiority complex confronts the historian, who must himself oppose the existential crisis that envelopes the whole process of inquiry.

Castro's effort to address his critics by defining his own historical methodology reveals the extent of the academic controversy surrounding his ideas. Again, not all have been critical of his ideas. Many scholars have been perhaps too enthusiastic in their appropriation of concepts such as convivencia, especially more recently as cultural studies have burgeoned. Indeed, Castro's idea of convivencia has proved to be the primary legacy through which historians have received him positively during the last half-century. These interpretations of convivencia, however, are often abridged in their own respect in that, while they work to avoid the filter of Castro's place in the debate on Spanish national character, they also fail to acknowledge the reality of violence in the construct. María Rosa Menocal's 2002 Ornament of the World represents a constituent of this idealistic reception of Castro's thought. While Menocal does not explicitly invoke convivencia, the basis of her book, how Andalusian Christians, Muslims, and Jews managed "to create a culture of tolerance" under the Umayyad Caliphate and to live in relative harmony beyond, does directly take up this debate. ${ }^{6}$ Like Castro, Menocal focuses on the cultural realm of production, and while she does acknowledge the place of violence in interfaith exchange, such as the Jewish massacre in Granada in 1066, she explains the impetus for such aberrations was foreign import. ${ }^{69}$ Also similar to Castro, Menocal roots her analysis in literary and linguistic sources, furthering the notion that while she does not explicitly invoke Castro as methodological inspiration, his influence is intrinsic to her text. The emphasis of her 
depiction of Islamic Andalusia on peaceful interfaith exchange does, however, distort the systemic reality of convivencia as Castro describes it.

Despite the optimism of such writers as Menocal, Castro's analysis of Saint James makes clear that convivencia is constituted by both peacetime and violent interaction between the Peninsula's religious groups. Several have explained the more nuanced reality of Castro's framework. Alisa Meyuhas Ginio, aware of the term's misuse, proclaimed the need for a more definitive term in its place that would alleviate its ambiguity. On account of Ginio's idea of the historical reality of medieval Spain, an idea not at all contrary to Castro's, where disparate ethnic and religious groups lived alongside one another sometimes peacefully, sometimes aggressively, Ginio suggests "coexistence" may be the more accurate term. ${ }^{70}$ However trivial Ginio's emphasis on this terminological distinction may seem, it exemplifies the reality of the confusion over what the term convivencia actually implies in Castro's thought. Thomas F. Glick, too, has made it clear that convivencia "carries connotations of mutual interpenetration and creative influence, even as it also embraces the phenomena of mutual friction, rivalry, and suspicion." ${ }^{71}$ David Nirenberg invoked this idealistic historiography of convivencia specifically in his 1996 text Communities of Violence: Persecution of Minorities in the Middle Ages, saying, "There is no reason why convivencia need designate only harmonious coexistence ... it has in fact acquired this meaning among historians who have romanticized the concept. ${ }^{72}$ Clearly not all of Castro's successors in the study of social interaction between Christians, Muslims, and Jews in the Middle Ages have appropriated his term of convivencia for the nominal suggestion of intergroup harmony. The reality is, again, much more complex, what Castro illustrates in his depiction of the rise of Saint James' cult. 
The historiography treating the cult of Saint James itself does not necessarily upset Castro's conception. Marlyn Stokstad, for example, suggested if it were not for the belief in Saint James' legend and relics, "the city of Santiago de Compostela would not have developed as it did." ${ }^{73}$ In this way the Saint's influence did play a central role in the making of Spain. Santiago de Compostela was the cult's foundation and by the eleventh and twelfth centuries, the most effusive monetary contributor to the growing efforts of reconquest. On the other hand, Kendrick argued explicitly that "the cult of Santiago never had an influence on Spanish history of the kind posited by Américo Castro. Compostela did not forge Spain. Compostela did not even enjoy uninterrupted success." ${ }^{74}$ But Kendrick's argument is understandably limited in that his approach to the history of Spain is far different than Castro's. Kendrick illustrates the circumstance of riots during the tenure of Diego Gelmírez in the early twelfth century without looking at the longue durée, or the literary evidence of the later Middle Ages, as Castro does. Moreover, Kendrick's book focuses on the origins of the myth of Saint James, whereas Castro focuses on the origins of the cult and its eventual growth into the spiritual impetus for the Reconquista. Even to consider the broader European context during the Middle Ages, such as that entailed of O'Callaghan's "pluralistic" perspective of the Crusades, adds layers of complexity to the understanding of the cult's rise to prosperity, but they and Castro's dialectical analysis are not mutually exclusive.

\section{Conclusion}

To examine Castro and his idea of Saint James in the historiography of the last halfcentury reveals certain trends and perspectives, but whether received positively or negatively, historians must understand that he operated within the context of a unique philosophy of history. His concepts, such as his idea of Saint James, are qualified within his own way of viewing the past. It is not inaccurate to consider Castro a polemicist against Franco-era Spain, but the irony 
of this claim is it represents Castro's work as responding directly to its structural circumstances, or in Castro's own terms, its own morada vital. In this way, when filtering his work through the debate on Spanish national character, Castro's critics are appropriating the very vitalist perspective they reject. It is necessary, then, to acknowledge as much. He says in The Structure of Spanish History, "History is understood if we contemplate it creating itself from within its particular mode of behavior, and not from without." ${ }^{75}$ A people's history can only be understood by viewing the people within their own worldview and structural circumstances. Effectively Castro's method of viewing history is the only method by which Castro may be understood. If historians at least express the relation of their conclusions about Castro as an author to his own philosophy of history, especially when invoking him within the context of a polemic, they will avoid hypocrisy, and add rationality to their own versions of history.

The twentieth century produced a range of scholars that have been categorized similarly to Don Américo. This group was not unique to Spain, not even to Europe, especially as colonial administrations produced contexts of oppression throughout the world similar to that of the Franco regime. All were intellectual obstructions, and for scholars such as Castro, all issued a higher calling for the expression of an oppressed people in existential terms, which, perhaps, allowed for the closest idea of reality attainable. The literature stemming from these circumstances deserves to be considered within its own context, on its own terms. Doing so will not only strengthen the revisionary scholarship that is to come; it will also work toward rooting out the hypocrisy of a Western age that claims to have realized the all-inclusive democracy, but still refuses to understand its oppressive past in the terms furnished by the literary expressions of its subjects. 
Kendrick concludes Saint James in Spain by reminiscing about the Spanish national holiday, 'El día de Santiago.' He describes the atmosphere of the festivities thus: "When the bells are ringing, and the rockets are hissing and banging, and inside the cathedral the tapers are lit and the air is heavy with incense, then, when, with the gently hesitant dignity of the litter-borne image, Santiago, on his fine horse and with his flashing sword, moves in procession among his people, even the most incredulous of us might fittingly pay this blood-thirsty image a discreet act of homage. After all, Santiago Matamoros has worked wonders in Spanish hearts." ${ }^{76}$ Little would Kendrick have known that Castro would die twelve years later, "swimming in the Mediterranean Sea, in the little Catalonian resort town of Lloret de Mar," on El día de Santiago, July $25,1972 .{ }^{77}$ Rubia Barcia had already commented on the coincidental date of Castro's death. For a historian who emphasized so adamantly Saint James' role in determining the Spanish living experience, it only seems appropriate to have passed away in the essence of what 'El día de Santiago' represented. To reflect, too, on Castro's philosophy of history, it becomes clear Castro was a man of his times. Whether his dialectic is the most appropriate for grasping the human experience of the Spanish in their history, it is certain that only via the dialectic may Castro as a historian be understood. 
Notes:

${ }^{1}$ Julián Marías, Los españoles (Madrid: Revista de Occidente, 1963), 206. "... but sometimes it forgets when its exterior mirrors reflect deformed and contradictory images of itself" (my translation).

${ }^{2}$ Américo Castro, The Structure of Spanish History, trans. Edmund L. King (Princeton: Princeton University Press, 1954), 17.

${ }^{3}$ Castro, Structure, 17.

${ }^{4}$ Castro, Structure, 17.

${ }^{5}$ José Rubia Barcia, "What's in a Name: Américo Castro (y Quesada)," in Américo Castro and the Meaning of Spanish Civilization, eds. José Rubia Barcia and Selma Margaretten (Berkeley: University of California Press, 1976), 18.

${ }^{6}$ Américo Castro, Santiago de España (Buenos Aires: Emecé Editores, 1958), 15, my translation.

${ }^{7}$ T.D. Kendrick, St. James in Spain (London: Methuen, 1960), 17.

${ }^{8}$ Kendrick, St. James in Spain, 17; disputed date, Fletcher notes that the date could not be earlier than 818, see R.A. Fletcher, St. James's Catapult: The Life and Times of Diego Gelmírez of Santiago de Compostela (Oxford:

Clarendon Press, 1984), 57.

${ }^{9}$ Fletcher, St. James's Catapult, 53.

${ }^{10}$ Katherine Elliott van Liere, "The Missionary and Moorslayer: James the Apostle in Spanish Historiography from Isidore of Seville to Ambrosio de Morales," Viator 37 (2006): 520.

${ }^{11}$ Qtd. in Fletcher, St. James's Catapult, 65.

${ }^{12}$ Fletcher, St. James's Catapult, 65.

${ }^{13}$ Qtd. in Mary-Ann Stouck, ed., A Short Reader of Medieval Saints (Toronto: Toronto University Press, 2009$), 108$.

${ }^{14}$ Derek W. Lomax, La Orden de Santiago 1170-1275 (Madrid: Consejo superior de investigaciones científicas, 1965), 5.

${ }^{15}$ Lomax, Orden de Santiago, 5.

${ }^{16}$ Lomax, Orden de Santiago, 5.

${ }^{17}$ Castro, Structure, 5 n. 2.

${ }^{18}$ Castro, Structure, 24.

${ }^{19}$ Castro, Structure, 25.

${ }^{20}$ Castro, Structure, 25.

${ }^{21}$ Castro, Structure, 25.

${ }^{22}$ Castro, Structure, 25.

${ }^{23}$ Castro, Structure, 32.

${ }^{24}$ Castro, Structure, 33.

${ }^{25}$ Castro, Structure, 33.

${ }^{26}$ Castro, Structure, 33.

${ }^{27}$ Castro, Structure, 33.

${ }^{28}$ Caroll B. Johnson, "The Classical Theater and its Reflection of Life," in Américo Castro and the Meaning of Spanish Civilization, eds. Rubia Barcia and Margaretten, 210.

${ }^{29}$ Castro, Structure, 82.

${ }^{30}$ Castro, Structure, 83.

${ }^{31}$ Castro, Structure, 79.

${ }^{32}$ Castro, Structure, 131.

${ }^{33}$ Castro, Structure, 127.

${ }^{34}$ Castro, Structure, 126.

${ }^{35}$ Castro, Structure, 127.

${ }^{36}$ Castro, Structure, 127.

${ }^{37}$ Castro, Structure, 131.

${ }^{38}$ Castro, Structure, 131.

${ }^{39}$ Castro, Structure, 131.

${ }^{40}$ Castro, Structure, 131.

${ }^{41}$ Castro, Structure, 151.

${ }^{42}$ Castro, Structure, 149.

${ }^{43}$ Castro, Structure, 131. 
${ }^{44}$ Castro, Structure, 183.

${ }^{45}$ Castro, Structure, 183.

${ }^{46}$ Castro, Structure, 25.

${ }^{47}$ Castro, Structure, 5 n. 2.

${ }^{48}$ Castro, Structure, 147.

${ }^{49}$ Castro, Structure, 157.

${ }^{50}$ Castro, Structure, 147.

${ }^{51}$ Castro, Structure, 147.

${ }^{52}$ Martín F. Ríos Saloma, La Reconquista en la historiografía española contemporánea (México D.F.: Universidad Nacional Autónoma de Méxcio, 2013), 54.

${ }^{53}$ Ríos Saloma, La Reconquista, 66.

${ }^{54}$ See Thomas F. Glick, Islamic and Christian Spain in the Early Middle Ages (Princeton: Princeton University Press, 1979).

55 Joseph F. O'Callaghan, Reconquest and Crusade in Medieval Spain (Philadelphia: University of Pennsylvania Press, 2003), 27.

${ }^{56}$ O'Callaghan, Reconquest and Crusade, 11.

57 José Luis L. Aranguren, "A New Model for Hispanic History," in Américo Castro and the Meaning of Spanish Civilization, eds. José Rubia Barcia and Selma Margaretten (Berkeley: University of California Press, 1976), 314.

58 Aranguren, "A New Model," 315.

${ }^{59}$ Castro, Structure, 45.

${ }^{60}$ Oriol Pi-Sunyer, "The Historiography of Américo Castro: An Anthropological Interpretation," Bulletin of Hispanic Studies 49.1 (1972), 41.

${ }^{61}$ Pi-Sunyer, "Anthropological Interpretation," 41.

${ }^{62}$ Pi-Sunyer, "Anthropological Interpretation," 41.

${ }^{63}$ Castro, Structure, 10.

${ }^{64}$ Castro, Structure, 44.

${ }^{65}$ Castro, Structure, 26.

${ }^{66}$ Castro, Structure, 26.

${ }^{67}$ Castro, Structure, 26.

${ }^{68}$ María Rosa Menocal, The Ornament of the World: How Muslims, Jews, and Christians Created a Culture of Tolerance in Medieval Spain (Boston: Little, Brown and Company, 2002), 11.

${ }^{69}$ Harold Bloom, preface to Ornament of the World, xiv.

${ }^{70}$ Alisa Meyuhas Ginio, "¿Convivencia o Coexistancia? Acotaciones al pensamiento de Américo Castro," in Creencias y culturas, eds. Carlos Carrete Parrondo and Alisa Meyuhas Ginio (Salamanca: Dirección General de Investigación Científica y Enseñanza Superior del Ministerio español, 1998), 157.

${ }^{71}$ Thomas F. Glick, "Convivencia: An Introductory Note," in Convivencia: Jews, Mulsims, and Christians in Medieval Spain, eds. Vivian B. Mann, et al. (New York: The Jewish Museum, 1992), 1.

${ }^{72}$ David Nirenberg, Communities of Violence: Persecution of Minorities in the Middle Ages (Princeton: Princeton University Press, 1996), 8.

${ }^{73}$ Marilyn Jane Stokstad, Santiago de Compostela in the Age of the Great Pilgrimages (Norman: University of Oklahoma Press, 1978), 6.

${ }^{74}$ Kendrick, St. James in Spain, 190.

${ }^{75}$ Castro, Structure, 41-42.

${ }^{76}$ Kendrick, St. James in Spain, 200.

${ }^{77}$ Rubia Barcia, "What's in a Name," 20. 


\section{Bibliography}

Aranguren, José Luis L. "A New Model for Hispanic History." In Américo Castro and the Meaning of Spanish Civilization, edited by José Rubia Barcia and Selma Margaretten, 309-316. Berkeley: University of California Press, 1976.

Castro, Américo. The Structure of Spanish History. Translated by Edmund L. King. Princeton: Princeton University Press, 1954.

---. Santiago de España. Buenos Aires: Emecé Editores, 1958.

Elliott van Liere, Katherine. "The Missionary and the Moorslayer: James the Apostle in Spanish Historiography from Isidore of Seville to Abrosio de Morales." Viator 37 (2006): 519-543.

Fletcher, R.A. St. James's Catapult: The Life and Times of Diego Gelmírez of Santiago de Compostela. Oxford: Clarendon Press, 1984.

Glick, Thomas F. Islamic and Christian Spain in the Early Middle Ages. Princeton: Princeton University Press, 1979.

---. "Convivencia: An Introductory Note." In Convivencia: Jews, Muslims, and Christians in Medieval Spain, edited by Vivian B. Mann, et. al., 1-7. New York: The Jewish Museum, 1992.

Johnson, Caroll B. "The Classical Theater and its Reflection of Life." In Américo Castro and the Meaning of Spanish Civilization, edited by José Rubia Barcia and Selma Margaretten, 193-220. Berkeley: University of California Press, 1976.

Kendrick, T.D. St. James in Spain. London, Methuen, 1960.

Lomax, Derek W. La Orden de Santiago 1170-1275. Madrid: Consejo superior de investigaciones científicas, 1965.

Marías, Julián. Los españoles. Madrid: Revista de Occidente, 1963.

Meyuhas Ginio, Alisa. "¿Convivencia o Coexistencia?: Acotaciones al pensamiento de Américo Castro." In Creencias y culturas, edited by Carlos Carrete Parrondo and Alisa Meyuhas Ginio, 140-162. Salamanca: Dirección General de Investigación Científica y Enseñanza Superior del Ministerio español, 1998.

Nirenberg, David. Communities of Violence: Persecution of Minorities in the Middle Ages. Princeton: Princeton University Press, 1996.

O'Callaghan, Joseph F. Reconquest and Crusade in Medieval Spain. Philadelphia: University of Pennsylvania Press, 2003. 
Pi-Sunyer, Oriol. "The Historiography of Américo Castro: An Anthropological Interpretation." Bulletin of Hispanic Studies 49.1 (1972): 40-50.

Ríos Saloma, Martín F. La Reconquista en la historiografia española contemporánea. México D.F.: Universidad Nacional Autónoma de México, 2013.

Rosa Menocal, María. The Ornament of the World: How Muslims, Jews, and Christrians Created a Culture of Tolerance in Medieval Spain. Boston: Little, Brown and Company, 2002.

Rubia Barcia, José. "What's in a Name: Américo Castro (y Quesada)." In Américo Castro and the Meaning of Spanish Civilization, edited by José Rubia Barcia and Selma Margaretten, 3-22. Berkeley: University of California Press, 1976.

Stokstad, Marilyn Jane. Santiago de Compostela in the Age of the Great Pilgrimages. Norman: University of Oklahoma Press, 1978.

Stouck, Mary-Ann, ed. A Short Reader of Medieval Saints. Toronto: Toronto University Press, 2009. 